УДК 502.64

DOI: $10.18384 / 2310-7189-2016-1-78-91$

\title{
ПРОИЗВОДСТВЕННАЯ ГЕОЭКОЛОГИЯ: АКТУАЛЬНАЯ ПРОБЛЕМАТИКА
}

\author{
Розанов ЛЛ. \\ Московский государственный областной университет \\ 105005, г. Москва, ул. Радио, д.10А, Российская Федерация
}

Аннотация. В статье рассматривается содержание понятий «геоэкологические процессы», «окружающая среда», «промышленная безопасность», «техносфера». Подход к техносфере как части биосферы методологически считаем неконструктивным. Отмечена научно-геоэкологическая необоснованность Монреальского (1987) и Киотского (1997) протоколов с позиций охраны окружающей среды и сомнение в целесообразности дальнейшего участия России в реализации этих Протоколов. Сфрормулированы задачи производственной геоэкологии как научно-прикладного направления, изучающего техногенные воздействия на состояние окружающей среды с целью предотвращения ее загрязнения и деградации в пространственно-временной конкретности.

Ключевые слова: геоэкологические процессы, окружающая среда, производственная геоэкология, промышленная безопасность, техносфрера.

\section{PRODUCTION GEOECOLOGY: CURRENT ISSUES}

\section{Rozanov \\ Moscow State Regional University \\ 10 A, Radio Street, Moscow, 105005, the Russian Federation}

Abstract. The content of such concepts as geoecological processes, environment, industrial safety and technosphere is discussed. The approach to the technosphere as part of the biosphere is considered methodologically unconstructive. The Montreal (1987) and Kyoto (1997) protocols are assumed scientifically and geoecologically groundless from the standpoint of environmental protection, which casts some doubt on the expediency of further participation of Russia in the implementation of these protocols. We have formulated the problems of industrial geoecology as a scientific and applied direction, studying anthropogenic impacts on the environment, to prevent pollution and degradation in the spatial and temporal specificity.

Key words: geoecological processes, environment, industrial geo-ecology, industrial safety, technosphere.

Парадокс современной техногенной цивилизации заключается в разрушении биосферы производственной и военной деятельностью при одновременном осознании ее значимости для жизни нынешних и будущих поколений людей. Человечество способно существовать в той биосфере, в которой оно возникло, поэтому слова В.И. Вернадского «человек может и должен перестраивать коренным образом биосферу» [4, с. 148] следует рассматривать в условиях современной

(с) Розанов Л.Л., 2016. 
действительности лишь относительно цели сохранения ее пригодности для жизнедеятельности людей. Человечеству угрожает не исчерпание доступных ресурсов, а опережающее ухудшение качества окружающей среды вследствие функционирования техносферы. Энергия мировой техносферы «утраивает свою мощность в среднем через каждые 15 лет. Вызванный ею технологический прессинг на природные экосистемы приводит их к необратимому разрушению, которое по своим масштабам быстро обретает глобальный характер» [20, с. 405].

Подход к техносфере как «части биосферы, коренным образом преобразованной человеком в технические и техногенные объекты (здания, дороги, механизмы и т.п.)» [11, с. 516] представляется методологически неконструктивным. Техносфера не является ни частью, ни ступенью развития биологической природы. Техногенный мир принципиально чужд биологическому миру. Техника - это творения сознательных людей, способ их самовыражения, средство коммуникации. Техника (в собирательном смысле машины, устройства) не есть функциональная часть биосферы, хотя в ней и находится. Действие техники, удовлетворяющей, прежде всего, материальные потребности человечества, относительно противостоит природе, дестабилизирует окружающую среду. Человечество, находясь в биосфере, нарушает и разрушает среду своего обитания [13]. Оно способно изменить структуру биосферы, но не имеет возможности изменить механизмы ее саморегуляции. Действенная предпосылка выживания человечества - соразвитие естественного и искусствен- ного, выражающееся в сопряженном взаимодействии природных и техногенных потоков вещества, энергии и информации, обусловливающих приемлемое для жизнедеятельности людей состояние геоэкологических ресурсов окружающей среды [16]. Создание равных условий для функционирования техносферы и биосферы возможно на основе геоэкологических знаний.

\section{Основные понятия}

Геоэкология - это формирующаяся междисциплинарная наука о современном и будущем состоянии окружающей среды, сохранении ее жизнеобеспечивающих ресурсов для нынешних и будущих поколений людей. Под окружающей средой понимается взаимодействующая совокупность естественных (природных), искусственных (техногенных) и переходных, промежуточных (техноплагенных) между ними веществ, тел, факторов, оказывающих прямое или косвенное влияние на людей, живые и неживые объекты природы и общества.

Окружающая среда для человека выступает обычно как природно-техногенное целое, состоящее из взаимосвязанных природных, техноплагенных (от лат. plaga - толчок), техногенных объектов и явлений, воздействующих на жизнь, здоровье, хозяйственную деятельность и отдых людей. Обобщающее представление об окружающей среде как природно-техногенном целом методологически принципиально для уяснения и упорядочения пространственно-временной геоэкологической информации, в том числе о геоэкологических процессах в «территориально-человеческом измерении». На современном уровне знаний 
геоэкологические процессы - это изменения здоровья и жизнедеятельности человека, перемены в состоянии растительных и животных организмов под прямым или опосредованным воздействием окружающей среды [15].

Прикладная геоэкология изучает взаимоотношения и взаимосвязи человека и его деятельности с окружающей средой на локальном, региональном, глобальном уровнях с целью их оптимизации. Производственная геоэкология - это направление прикладной геоэкологии, изучающее техногенные воздействия на состояние окружающей среды с целью предотвращения ее загрязнения и деградации в пространственно-временной конкретности [14].

\section{Геоэкологическая проблемность современного производства}

Для удовлетворения потребностей человек создает и совершенствует технику с целью превращения одной вещественно-энергетической предметности в другую. Выбросы загрязнителей промышленного производства влияют не столько на само предприятие, сколько на население, сельские и лесные угодья, природные экосистемы. В зависимости от вида производственной деятельности вблизи и на удалении от источников выбросов формируются техногенные геохимические аномалии со специфическими ассоциациями загрязняющих окружающую среду веществ. Загрязняющие вещества (металлы и металлоиды, синтезированные органические ксенобиотики, природные токсины - см. табл.) оказывают на человека прямое влияние и непрямое (опосредованное) через изменение окружающей среды.
Обсуждение геоэкологической проблемности современного производства следует начать с ядерной энергетики, поскольку «любая идеально работающая АЭС оказывает влияние на окружающую среду, распространяя радионуклиды» [24, с. 62]. Радионуклиды - химические элементы, способные самопроизвольно распадаться с испусканием ионизирующего излучения (альфа-частицы, бета-частицы, гамма-излучение), которое при проникновении в организм человека разрушает клетки, вызывая различные болезни. Вследствие атомного природопользования «идет постоянное генерирование «глобальных» (криптон-85, радиоуглерод, тритий), «вечных» (плутоний-239, плутоний-240, йод129, америций-241) и просто долгоживущих радионуклидов - таких, как цезий, стронций, технеций и др. Вред трития общепризнан - его содержание в водах водоемов вблизи всех крупных предприятий ядерно-топливного цикла (ЯТЦ) выше глобального в 3-10 раз» [2, с. 158].

Тритий (радиоактивный водород), образующийся в любом реакторе при действии нейтронов на водородсодержащие вещества (в частности на воду), способен при нагревании проникать через его стальные стенки. Не существует фильтров, способных задержать этот радионуклид, поэтому грунтовые воды вокруг всех АЭС загрязнены тритием. Попадая в протоплазму живых клеток, тритий распадается, превращается в гелий, испускающий бета-излучение, поражающее генетический аппарат клеток живых организмов [24]. Техногенное радиационное загрязнение биосферы - одна из главных причин увеличения 
Таблица

\section{Техногенные ассоциации загрязнителей окружающей среды (по Т.И.Моисеенко [10] с дополнениями автора)}

\begin{tabular}{|c|c|}
\hline Вид производства & Химические элементы и токсичные вещества \\
\hline Ядерная энергетика & Радионуклиды: Kr-85, H-3, C-14, C-41, \\
\hline Теплоэнергетика на угле & $\begin{array}{l}\text { Pu-239+240, J-129, Am-241, Cs-137, Sr-90, Co-60 и дp. } \\
\mathrm{Hg}, \mathrm{Br}, \mathrm{Cl}, \mathrm{F}, \mathrm{Se}, \mathrm{B}, \mathrm{Zn}, \mathrm{As}, \mathrm{Cd}, \mathrm{Ga}, \mathrm{Ge}, \mathrm{Pb}, \mathrm{Sn}, \mathrm{Te}, \mathrm{Co}, \mathrm{Cr} \\
\mathrm{Mo}, \mathrm{Ni}, \mathrm{Cu}, \text { радионуклидь: K-40, U-238, Ra-226, Pb-210, } \\
\text { Po-210 }\end{array}$ \\
\hline $\begin{array}{l}\text { Горно-обогатительные и пла- } \\
\text { вильные: }\end{array}$ & \\
\hline медно-никелевое & $\mathrm{Cu}, \mathrm{Ni}, \mathrm{Co}, \mathrm{Ba}, \mathrm{Pb}, \mathrm{Zn}, \mathrm{Ag}, \mathrm{Cd}$ \\
\hline колчеданно-полимерное & $\mathrm{Zn}, \mathrm{Cd}, \mathrm{Pb}, \mathrm{As}, \mathrm{Ag}, \mathrm{Se}$ \\
\hline ртуттно-сурьмяное & $H g, S b, A s, T e, A g, B i, Z n, M o$ \\
\hline полиметаллическое & $\mathrm{Pb}, \mathrm{Zn}, \mathrm{Cu}, \mathrm{Ag}, \mathrm{Cd}, \mathrm{Hg}, \mathrm{As}, \mathrm{Mo}$ \\
\hline апатитонефелиновое & $P, A l, S r, R b, C e$ \\
\hline алюминиевое & $A l, F$, бенз $(a)$ пирен \\
\hline $\begin{array}{l}\text { Машиностроение и металлоо- } \\
\text { бработка }\end{array}$ & B, Co, Cr, Cu, Mn, Mo, Ni, Pb, Sc, Sn, V, W, Zn, ПХБ, ПАУ \\
\hline Химическое и небтехимическое & $\begin{array}{l}\mathrm{Ag}, \mathrm{Bi}, \mathrm{Cd}, \mathrm{Co}, \mathrm{Cu}, \mathrm{Hf}, \mathrm{Hg}, \mathrm{Mo}, \mathrm{Hb}, \mathrm{Ni}, \mathrm{Pb}, \mathrm{Sb}, \mathrm{Sn}, \mathrm{W}, \mathrm{Zn}, \\
\text { нефтепродукты, ПАУ, ПХБ, ПХДД, ПХДФ, феноль, } \\
\text { формальдегиды }\end{array}$ \\
\hline $\begin{array}{l}\text { Деревообрабатывающее и } \\
\text { целлюлозно-бумажное }\end{array}$ & $\begin{array}{l}\text { Лигносульфатьы, фенольь, меркаптан, } \mathrm{Hg}, \mathrm{Cu}, \mathrm{Al} \text {, As u } \\
\text { др. }\end{array}$ \\
\hline Сельскохозяйственное & $P, N, C d$, nестициды (ДДТ, ГХЦГ и др.) \\
\hline $\begin{array}{l}\text { Отходы производств урбани- } \\
\text { зированных территорий }\end{array}$ & $\begin{array}{l}P b, Z n, C u, C d, H g, A g, S n, C r, N i, C d, H g, W, \Pi A У, \Pi Х Б, \\
\text { ПХДД, ПХДФ }\end{array}$ \\
\hline
\end{tabular}

Прим.: ДДТ - дихлордифенилтрихлорэтан; ГХЦГ - гексахлорциклогексан; ПАУ - полициклические ароматические углеводороды; ПХБ - полихлорированные бифенилы; ПХДД - дибензопарадиоксины; ПХДФ - полихлорированные дибензофураны.

онкологической заболеваемости, которая занимает второе место в мире по смертности. Согласно В.И. Булатову [3], в России имеется 1\% загрязненных и до $10 \%$ слабозагрязненных и потенциально опасных в ядерном отношении территорий.

В последнее время отмечаются погодные аномалии. Выбросы радионуклида криптон-85 в атмосферу в миллионы раз превысили уровень, наблюдавшийся до начала функционирования АЭС в мире [24]. В 2011 г., по данным международного агентства по атомной энергии (МАГАТЭ), в 32 странах мира работали 440 атомных реакторов, размещенных на 212 АЭС, в том числе 104 энергоблока на 68 АЭС в США. По результатам исследований, неприятные последствия появления огромного количества криптона- 85 заключаются в увеличении электропроводности атмосферы, вызывающей изменения магнитного поля Земли и характера осадков, увеличения электризации гроз, числа торнадо (смерчей). Техноплагенное накопление криптона-85 геоэкологически и геофи- 
зически проявляются в загрязнении и изменении свойств окружающей среды, что сопровождается усилением метеотропных реакций и увеличением заболеваемости населения. Криптон-85 поглощается тканями тела, даже малые дозы облучения им могут повысить частоту возникновения рака кожи [24].

В отличие от атомных электростанций, геоэкологическая опасность которых после аварии на Чернобыльской АЭС вызывает повышенную тревогу граждан, тепловые электростанции (ТЭС) считаются более приемлемыми. Между тем, по опубликованным данным, в результате выработки каждого миллиарда кВт/ч энергии эти станции выбрасывают в воздушную среду 1 млн. т $\mathrm{CO}_{2}$, не считая других вредных веществ. В России 172 углесжигающих ТЭС, вокруг них накоплено около 2 млрд. т золы и шлаков, масса которых возрастает на 25-30 млн.т/год. Суммарная площадь золошлакоотвалов в РФ

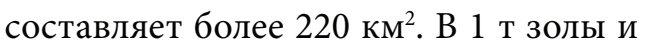
шлаков могут содержаться до 90 кг железа, 160 кг алюминия, 10-30 кг магния, 1-3 кг титана, 1 кг редких металлов, что представляет собой техногенное минеральное сырье для предприятий черной и цветной металлургии.

В настоящее время в России используется до 10\% золы ТЭС. В золошлаковых отходах от сжигания углей содержатся, как правило, не только тяжелые металлы, но и уран, торий, калий-40 и продукты их распада - радий, полоний и др. Установлено, что уровень радиоактивного загрязнения в окрестностях угольных станций даже выше, чем вокруг АЭС. Поэтому при проектировании и строительстве ТЭС предусматривается оснащение их средствами очистки выбросов и сбросов загрязняющих веществ, использование безвредных видов топлива и безопасное размещение токсичных отходов. В свете новой индустриализации России основу производства, очевидно, будет составлять использование техногенных ресурсов [9].

Появление диоксинов в окружающей среде представляет для человека опасность не меньшую, чем радиоактивное загрязнение (тем более, что обнаружить диоксины гораздо сложнее, чем радионуклиды). Диоксины чрезвычайно токсичные органические соединения канцерогенного, тератогенного, мутагенного действия, относящиеся к классу полихлорированных дибензодиоксинов. Они образуются при производстве хлора, брома, йода, фтора в качестве побочных веществ. Диоксины выделяются при пожарах в лесах, обработанных хлорсодержащими пестицидами, при сжигании бытового мусора, включающего синтетические хлоруглеродные материалы, а также автотранспортом. Источники диоксинов - предприятия коммунального хозяйства (полигоны твердых бытовых отходов, мусоросжигающие заводы). Диоксинами загрязнены практически все хозяйственно развитые регионы страны.

Для диоксинов установлены эффекты биологического умножения по трофическим цепям. Попав из окружающей среды в организм животных или человека, диоксины запускают сложные каскады реакций, способствующих нарушениям клеток вплоть до их некроза [17]. Согласно имеющимся расчетам, смертельная доза диоксина для человека при однократном поступлении в организм составляет 70 мкг/ 
кг массы тела. «Диоксины попадают в продукты двумя основными путями: из отравленной ими почвы и воды, а также из загрязненной тары и оборудования» [22, с. 34].

Проблему диоксинов невозможно решить без отказа от повсеместного использования хлора и его соединений в промышленных процессах получения полимерных материалов. Широкое применение полихлорированных бифенилов (ПХБ) в электротехнической промышленности (конденсаторы, трансформаторы), при производстве различных синтетических материалов, в сельском хозяйстве (борьба с переносчиками инфекционных заболеваний) обусловило интенсивное циркулирование их в окружающей среде. Сильно выраженные канцерогенные и мутагенные свойства бифенилов делают их особо опасными из-за способности аккумулироваться в экосистемах по трофическим цепям. Отравление человека от ПХБ проявляется в поражении внутренних органов (печень, почки, селезенка), в подавлении у людей иммунитета, провоцирования развития злокачественных новообразований.

Опасения по поводу возможных рисков и побочных эффектов нанотехнологий становятся предметом инженерных, естественнонаучных, социально-гуманитарных, геоэкологических исследований. Наноматериал - это вещество атомно-молекулярного уровня, геометрический размер которого хотя бы в одном измерении не превышает 100 нм (в международной системе единиц нанометр равен $\left.10^{-9} \mathrm{M}\right)$. Появление новых источников минеральных наночастиц, постоянный рост их интенсивности «неиз- бежно оказывает влияние на биоту», а «появление повышенных количеств сверхтонкой (плавающей) пыли в рудничной атмосфере резко повышает опасность для здоровья людей» $[21$, с. 318-319]. Проветривание горных предприятий приводит к выносу в воздушную среду техногенных наночастиц, создающих дополнительную пока недостаточно исследованную геоэкологическую проблему.

В современных реалиях развертывания транснациональными корпорациями (ТНК) трансгенного растениеводства (охватившего уже 13\% всех посевных площадей в мире), накопления негативных последствий применения генетически модифицированных организмов (ГМО), потребления продуктов, полученных на основе ГМО, становится злободневной сущность такого вида агробизнеса. В результате генной инженерии получены многие виды ГМ-растений, включая зерновые и зернобобовые культуры (кукурузу, пшеницу, рапс, рис, рожь, сорго, сою, ячмень), овощи (баклажаны, кабачки, картофель, лук, морковь, огурец, перец, томат, цветную капусту, чеснок), фрукты (ананас, арбуз, банан, виноград, клубника, киви, слива, яблоко). Суммарная площадь посевов в мире генномодифицированных культур занимает 190 млн. га. В условиях истощения ресурсов биологических разрастается глобальный кризис на рынке продовольствия, что обусловит навязывание товаров-продуктов, полученных на основе ГМО. В свете этого «обращено внимание на необходимость совершенствования нормативно-правовой базы РФ в области регулирования использования ГМО» [23, с. 50]. Накапливающиеся негатив- 
ные последствия применения генетически модифицированных организмов (ГМО), потребления продуктов, полученных на их основе, очевидно, свидетельствуют о возможности двойного предназначения такого вида агробизнеса транснациональных корпораций (ТНК). Реализация долговременной программы ГМО может привести к существенному сокращению численности населения планеты из-за утраты способности к воспроизводству потомства.

\section{Производственная геоэкология в свете Монреальского и Киотского протоколов}

При проведении международного сотрудничества в области геоэкологической политики важно исключать возможность взятия Россией таких обязательств, которые бы помешали в перспективе ее собственному развитию. Как известно, «озоновые дыры» с прежним постоянством появляются совсем не там, где им следовало бы появляться в соответствии с хлорной моделью гипотезы, лежащей в основе Монреальского протокола по веществам разрушающим «озоновый слой» (открытого к подписанию в 1987 г.). Несмотря на действие Монреальского протокола по запрещению так называемых озоноразрушающих веществ, согласно мировым наземным озонометрическим наблюдениям и спутниковым данным (полученным аппаратурой производства США и западноевропейских стран) в последние 30 лет постоянно фиксируется весенняя (сентябрь-октябрь) Антарктическая озоновая аномалия (или «озоновая дыра»).

После ратификации странами Монреальского протокола (о прекраще- нии производства озоноразрушающих веществ) наступила пора запретов и уничтожения производства фреонов и холодильной промышленности в России и в Европе. В США объем выпуска холодильного компрессорного оборудования вырос на 60\%. Для России очевидный итог Монреальского протокола - утрата (с 1996 г.) отечественных рынков холодильного промышленного оборудования и рабочих мест на закрытых заводах. Производившая до 1991 г. треть мирового выпуска хладонов, сегодня Россия практически ничего не производит, а только покупает «озонобезопасные» хладоагенты в Китае через американских посредников. Транснациональные корпорации (ТНК) получили новые рынки целого государства посредством реализованной бизнесидеи Монреальского протокола [8]. Геоэкологическим итогом навязанного Монреальского протокола является изъятие из производства безопасных для людей фреонов и хладонов, заполнение баллончиков и холодильников отравляющими веществами.

Внутреннее содержание Монреальского протокола состоит не в охране окружающей среды. Установлено, что «решающую роль в разрушении озонового слоя играют эндогенные источники, а именно дегазация земных недр» [19, с. 48]. Поступающий из центров дегазации водород и метан, взаимодействуя с озоном, разлагают его, приводя к возникновению так называемых «озоновых дыр». Заявленные причины создания Монреальского протокола «не нашли научного подтверждения, а цикличность и интенсивность образования озоновых дыр, несмотря на прекращение выпуска хлорсодержащих фреонов, остались 
неизменными» [8, с. 20]. Примечателен вывод российских ученых: «Монреальский протокол за двадцать лет существования не решил задачи, ради которых его приняли Страны-участницы. Прошедшие двадцать лет можно считать потерянным временем в глобальной задаче охраны окружающей среды. Монреальский протокол несет в себе признаки экономического сговора Стран-участниц, принятого в целях навязывания суверенным странам кабальных условий товарообмена, что противоречит принципам свободной торговли» [8, с. 13].

Проблема нового соглашения о сокращении выбросов парниковых газов (поскольку срок действия Киотского протокола истек в 2012 г.) стала предметом острых дискуссий. Киотский протокол (декабрь 1997 г.) юридически обязывал его участников на ограничение и снижение промышленных выбросов углекислого газа. В свете этого приведем точку зрения английского ученого С. Бомер-Кристиансена [1, с. 27, 28-29, 32] о том, что Киотский протокол «служит инструментом с целью создания рынков для новых видов топлива и технологий, в которых ЕС надеется обладать преимуществами лидера»; «так называемое «глобальное потепление» стало инструментом для решения ряда политических проблем, которые не популярны и даже лишены обоснования в рамках ЕС»; «технологические изменения, предусмотренные Протоколом Киото, направлены на радикальное изменение энергетики, выгодное в первую очередь лишенному достаточных энергетических ресурсов Европейскому союзу».

Несмотря на регистрируемый рост концентрации углекислого газа в ат- мосфере, инструментальными наблюдениями установлены периоды понижения средней годовой приземной температуры воздуха. Согласно графику ее динамики [7], достаточно заметное похолодание проявилось с 1879 г. $\left(13,8^{\circ} \mathrm{C}\right)$ по 1911 г. $\left(13,5^{\circ} \mathrm{C}\right)$ на $0,3^{\circ} \mathrm{C}$ за 32 года; другое похолодание с 1941 г. $\left(14^{\circ} \mathrm{C}\right)$ по 1972 г. $\left(13,8^{\circ} \mathrm{C}\right)$ составило $0,2^{\circ} \mathrm{C}$ за 31 год, что не согласуется с так называемым парниковым эффектом углекислого газа. В свете «модельных прогнозов климатических изменений, связанных с накоплением антропогенных «парниковых» газов (особенно углекислого)», подчеркнуто, что с 1970-х гг. «последнее тридцатилетнее потепление было вызвано только усилением солнечной активности. А повышение парциального давления углекислого газа к этому не имело никакого отношения». Поэтому «надо готовиться к наступающему похолоданию» через 30 лет «во всяком случае, в Северном полушарии» $[18$, с. 31$]$.

Продолжение участия в реализации Киотского протокола при принятии жестких механизмов его регулирования позволит Европейскому Союзу ограничить приток на свой рынок российских товаров, обладающих повышенной энергоемкостью. С учетом современных геоэкологических и экономических реалий России вряд ли необходимо участвовать в выполнении Киотского протокола, не имеющего научного обоснования. Политизированный Киотский протокол по снижению промышленных эмиссий $\mathrm{CO}_{2}$ игнорирует «усиленное поступление в атмосферу парниковых газов в последние десятилетия в результате уникальной тектонической активности» [12, c. 178], выражающейся в увеличении 
в период 1900-2012 гг. вулканических извержений с 24 до 39 в год. Киотский протокол не рассматривает теплоотдачу от подстилающей поверхности из-за изменения ее отражательной способности (в том числе вследствие возрастания площади геотехноморфогенных поверхностей с низким альбедо), от различных производств, трубопроводов теплосети, зданий и других факторов.

Инструменты снижения «парникового эффекта» глобального потепления (Киотский протокол, 1997), а также меры защиты так называемого «озонового слоя» (Монреальский протокол, 1987) - это научно не обоснованные решения геоэкологических проблем в условиях развернутой в мире информационно-сетевой войны. С позиций охраны окружающей среды и здоровья людей актуально «возрождение в России производства фреонов, безопасных для человека, как и возрождение отечественной холодильной промышленности, поскольку ТНК, захватившие рынки России, добровольно выполнять медицинские нормативы России не будут» [8, с. 26].

\section{Задачи производственной геоэкологии}

Изучение загрязнения, деградации окружающей среды, возникающих в результате функционирования разнообразных производств, использующих природные ресурсы - научно-практическое направление производственной геоэкологии. В производственно-геоэкологическом исследовании принципиален подход с позиций промьциленной безопасности, под которой понимается состояние объекта, предприятия, производства, опреде- ляемое комплексом технических и организационных мер, обеспечивающее стабильность параметров технологического процесса и, таким образом, сводящее к минимуму возможность возникновения аварийной ситуации, опасных ее воздействий на людей. Насущна проблема выделения в угольных шахтах вместе с метаном избыточного водорода, являющегося источником взрыва. В достижении промышленной безопасности важную роль играет научно-техническое нормирование, предполагающее введение ограничений хозяйственной деятельности в отношении поступления от источников воздействия вредных веществ в воздух, воду, почву.

Обеспечение промышленной безопасности предполагает определение уровня рисков, подготовленность к аварийным ситуациям, проведение мониторинга и корректирующих действий, направленных на охрану окружающей среды. Построение системы промышленной безопасности должно основываться на процессном подходе, позволяющем рассматривать всю деятельность предприятия как совокупность взаимосвязанных процессов, своевременно реагировать на внутренние и внешние изменения с целью оптимизации выполнения общественных и законодательных требований к производству продукции и к любым побочным отходам, сточным водам и выбросам в окружающую среду.

В «постнефтяном» периоде экономического развития России, очевидно, будет доминировать производство водоемкой продукции. Как известно, исключительно водоемкими являются металлургическое производство, нефтеоргсинтез, химия полимеров. 
Поэтому геоэкологическое обоснование устойчивого водопользования, неистощимости эксплуатации и воспроизводства водных ресурсов - приоритетная задача функционирования водохозяйственного комплекса страны в условиях обостряющегося мирового дефицита пресной воды. Для России может оказаться выгодной торговля водоемкой продукцией сельского хозяйства. Экспорт же пресной воды после вступления России (2012 г.) во Всемирную торговую организацию (ВТО) требует соблюдения сложных правил международной торговли. «С правовой точки зрения, ВТО способна контролировать, лимитировать или регулировать крупномасштабную торговлю водой» $[6$, с. 341].

С позиций конкурентных преимуществ эффективной стратегией для России в XXI в. может стать, наряду с развитием топливно-энергетического комплекса, геоэкологически рациональное сельское, лесное, воднобиологическое хозяйство. В свете реалий техногенной цивилизации [5] перспективы производственной геоэкологии как научной и учебной дисциплины заключаются в развитии следующих направлений:

- переориентация хозяйства с невозобновимых на возобновимые ресурсы;

- многократное использование невосполнимых ресурсов;

- использование техногенных ресурсов как основы производства;

- формирование отраслей по переработке уже созданных отходов;

- производство новых биоразлагаемых материалов (для тары);

- создание сверхгидрофобных материалов (имеющих специальную структуру на наноуровне), поверхности ко- торых не загрязняются, что приведет к сокращению использования воды для мытья, очистки машин и механизмов в условиях дефицита пресной воды;

- формирование системы регулирования генно-инженерной деятельности и биобезопасности оборота генетически модифицированных организмов (ГМО);

- разработка мониторинга воздействия на человека и окружающую среду генетически модифицированных организмов (ГМО) и продукции, полученной с применением таких организмов или их содержащих.

Особенности техногенной деградации окружающей среды определяют приоритеты производственной геоэкологии в воспроизводстве геоэкологических ресурсов жизнеобеспечения человека в пространственно-временной конкретности.

Выводы. Производственная геоэкология - научно-прикладное направление, изучающее техногенные воздействия на состояние окружающей среды с целью предотвращения ее загрязнения и деградации на различных иерархических уровнях. Функционирующая техносфера, не являющаяся ни частью, ни ступенью развития биосферы, дестабилизирует окружающую среду. Производственная и военная деятельность человечества нарушает и разрушает биосферу при осознании ее значимости для жизни нынешних и будущих поколений людей. В многообразном воздействии производства на окружающую среду выделены геоэкологически особо опасные для жизнедеятельности человека. К наиболее геоэкологически проблемным относятся ядерная энергетика, теплоэнергетика 
на угле, трансгенное растениеводство, связанные с выделением диоксинов и наночастиц производства.

В обстановке развязанной информационно-сетевой войны внимание к так называемым «озоновым дырам», глобальному потеплению климата служит инструментом создания новых рынков для транснациональных корпораций (ТНК). Накапливающиеся негативные последствия применения генетически модифицированных организмов (ГМО), потребления продуктов, полученных на основе ГМО, вызывают необходимость рассмотрения (изучения) трангенного растениеводства как особого (очевидно, двойного) вида агробизнеса. Реализация транснациональными корпорациями (ТНК) долговременной программы ГМО может привести к существенному сокра- щению численности населения из-за утраты способности к воспроизводству потомства.

В условиях современной глобализации, выражающей экономические и политические интересы транснациональных корпораций (ТНК), геоэкологически принципиально исключить возможность взятия Россией таких международных обязательств, которые бы помешали в перспективе ее собственному устойчивому развитию. Очевидно, актуальность производственной геоэкологии будет возрастать при принятии политико-экономическим менеджментом решений по оздоровлению окружающей человека среды, обеспечению государственных (национальных) интересов, сохранению геоэкологического суверенитета и потенциала России.

\section{ЛИТЕРАТУРА}

1. Бомер-Кристиансен С. Что движет процессом Киото: наука или интересы? // Известия Русского географического общества. 2004. Т. 136 (вып. 2). С. 26-32.

2. Булатов В.И. Радиоактивное загрязнение России // Экология, политика и гражданское общество. М.: РОДП «Яблоко», 2014. С. 151-173.

3. Булатов В.И. Атомное природопользование и радиоактивное загрязнение в России // География и природные ресурсы. 2015. № 2. С. 13-21.

4. Вернадский В.И. Биосфера и ноосфера. М.: Наука, 1989. 264 с.

5. Данилов-Данильян В.И., Лосев К.С., Рейф И.Е. Перед главным вызовом цивилизации: взгляд из России. М.: ИНФРА-М, 2005. 224 с.

6. Данилов-Данильян В.И. Рынки воды и водохозяйственных услуг в мире и Российской Федерации / В.И. Данилов-Данильян, А.П. Демин, В.Г. Пряжинская и др. // Водные ресурсы. 2015. Т. 42 (№ 3). С. 329-342.

7. Клиге Р.К. Глобальные изменения природных условий и воздействие на них гелиокосмических факторов // Атлас временных вариаций природных, антропогенных и социальных процессов [Том 5: Человек и три окружающие его среды]. М.: Янус-К, 2013. C. 19-51.

8. Мазурин И.М., Королёв А.Ф., Уткин Е.Ф. Монреальский протокол - 20 лет спустя // Система «Планета Земля» (нетрадиционные вопросы геологии): мат-лы XVI научного семинара Геологического ф-та МГУ. М.: Книжный дом «ЛИБРОКОМ», 2008. С. 13-28.

9. Малинецкий Г.Г. Техногенные ресурсы в контексте новой индустриализации России // Вестник Российской академии наук. 2015. Т. 85 (№ 4). С. 344-350.

10. Моисеенко Т.И. Водная экотоксикология: теоретические и прикладные аспекты. М.: Наука, 2009. 400 c. 
11. Реймерс Н.Ф. Природопользование: словарь-справочник. М.: Мысль, 1990. 640 с.

12. Ретеюм А.Ю. О роли эмпирических обобщений // Владимир Иванович Вернадский и история науки (к 150-летию со дня рождения): сб. докл. междунар. науч. конф. (г. Москва, 22 янв. 2013 г.). М.: АКСИ-М, 2013. С. 177-182.

13. Розанов Л.Л. Геоэкология: учебно-методич. пособ. для вузов. М.: Дрофа, 2010. 272 с.

14. Розанов Л.Л. Актуальные аспекты прикладной геоэкологии // Вестник Московского государственного областного университета. Серия: Естественные науки. 2013. № 4. C. 46-53.

15. Розанов Л.Л. Методологический аспект геоэкологии // Вестник Московского государственного областного университета. Серия: Естественные науки. 2015. № 2. С. 46-56.

16. Розанов Л.Л. Геоэкологоведение: итоги и перспективы // Вестник Московского государственного областного университета. Серия: Естественные науки. 2015. № 3. С. 5465.

17. Румак В.С. Воздействие диоксинов на окружающую среду и здоровье человека / В.С. Румак, Чинь Куок Кхань, А.Н. Кузнецов и др. // Вестник Российской академии наук. 2009. Т. 79 (№ 2). С. 124-130.

18. Сорохтин О.Г. Глобальное потепление: причины истинные и мнимые // Наука в России, 2010. № 2. С. 25-31.

19. Сывороткин В.Л. Водород - разрушитель озона // Наука в России. 2000. № 2. С. 47-53.

20. Трубецкой К.Н., Галченко Ю.П. Человек и природа: противоречия и пути их преодоления // Вестник РАН. 2002. Т. 72 (№ 2). С. 405-409.

21. Трубецкой К.Н. Техногенные минеральные наночастицы как проблема освоения недр / К.Н. Трубецкой, С.Д. Викторов, Ю.П. Галченко и др. // Вестник РАН. 2006. Т. 76 (№ 4). С. 318-324.

22. Фрумин Г.Т. Экология и геоэкология: мифы и реальность. СПБ.: РГГМУ, 2011. 236 с.

23. Шестибратов К.А., Чубугина И.В., Завриев С.К. Генно-инженерная деятельность: анализ международных и российской законодательных баз // Мировая экономика и международные отношения. 2014. № 12. С. 50-59.

24. Яблоков А.В. Об «экологической чистоте» атомной энергии // Глобальные проблемы биосферы [Вып. 1]. М.: Наука, 2003. С. 62-94.

\section{REFERENCES}

1. Bomer-Kristiansen S. Chto dvizhet protsessom Kioto: nauka ili interesy? [What drives Kioto] // Izvestiya Russkogo geograficheskogo obshchestva. 2004. Vol. 136 (iss. 2). pp. 26-32.

2. Bulatov V.I. Radioaktivnoe zagryaznenie Rossii [Radioactive contamination of Russia] Ekologiya, politika i grazhdanskoe obshchestvo [Ecology, policy and civil society]. M., RODP «YAbloko», 2014. pp. 151-173.

3. Bulatov V.I. Atomnoe prirodopol'zovanie i radioaktivnoe zagryaznenie v Rossii [Environmental management of nuclear and radioactive pollution in Russia] // Geografiya i prirodnye resursy. 2015. no. 2. pp. 13-21.

4. Vernadskii V.I. Biosfera i noosfera [The biosphere and the noosphere]. M., Nauka, 1989. 264 p.

5. Danilov-Danil'yan V.I., Losev K.S., Reif I.E. Pered glavnym vyzovom tsivilizatsii: vzglyad iz Rossii [Before the main call of civilization: a view from Russia]. M., INFRA-M, 2005. $224 \mathrm{p}$.

6. Danilov-Danil'yan V.I., Demin A.P., Pryazhinskaya V.G. et al. Rynki vody i vodokhozyaistvennykh uslug v mire i Rossiiskoi Federatsii [Water markets and water services in the world and the Russian Federation] // Vodnye resursy. 2015. Vol. 42 (no. 3). pp. 329-342.

7. Klige R.K. Global'nye izmeneniya prirodnykh uslovii i vozdeistvie na nikh geliokosmicheskikh faktorov [Global changes in natural conditions and the impact on heliocosmic fac- 
tors] // Atlas vremennykh variatsii prirodnykh, antropogennykh i sotsial'nykh protsessov [Tom 5: Chelovek i tri okruzhayushchie ego sredy] [Atlas of time variations of natural, anthropogenic and social processes [Vol. 5: the Man and three of his surrounding environments]]. M.: YAnus-K, 2013. pp. 19-51.

8. Mazurin I.M., Korolev A.F., Utkin E.F. Monreal'skii protokol - 20 let spustya [The Montreal Protocol - 20 years later] // Sistema «Planeta Zemlya» (netraditsionnye voprosy geologii): mat-ly XVI nauchnogo seminara Geologicheskogo f-ta MGU. ["Planet Earth" system (non-traditional questions of Geology): Proceedings XVI scientific workshop of the Geological faculty of Moscow state University.]. M.: Knizhnyi dom «LIBROKOM», 2008. pp. 13-28.

9. Malinetskii G.G. Tekhnogennye resursy v kontekste novoi industrializatsii Rossii [Technogenic resources in the context of the new industrialization of Russia] // Vestnik Rossiiskoi akademii nauk. 2015. Vol. 85 (no. 4). pp. 344-350.

10. Moiseenko T.I. Vodnaya ekotoksikologiya: teoreticheskie i prikladnye aspekty [Aquatic ecotoxicology: theoretical and applied aspects]. M.: Nauka, 2009. 400 p.

11. Reimers N.F. Prirodopol'zovanie: slovar'-spravochnik [Management: Dictionary-Handbook]. M.: Mysl', 1990. 640 p.

12. Reteyum A.YU. O roli empiricheskikh obobshchenii [On the role of empirical generalizations] // Vladimir Ivanovich Vernadskii i istoriya nauki (k 150-letiyu so dnya rozhdeniya): sb. dokl. mezhdunar. nauch. konf. (Moskva, 22 yanv. 2013 g.) [Vladimir Ivanovich Vernadsky and the history of science (on the 150th anniversary of the birthday), proc. int. sci. conf. (Moscow, 22 Jan. 2013)]. M.: AKSI-M, 2013. pp. 177-182.

13. Rozanov L.L. Geoekologiya: uchebno-metodich. posob. dlya vuzov [Geoecology: educational-methodical textbook for universities]. M.: Drofa, 2010. 272 p.

14. Rozanov L.L. Aktual'nye aspekty prikladnoi geoekologii [Current aspects of applied geoecology] // Vestnik Moskovskogo gosudarstvennogo oblastnogo universiteta. Seriya: Estestvennye nauki. 2013. no. 4. pp. 46-53.

15. Rozanov L.L. Metodologicheskii aspekt geoekologii [Methodological aspects of geoecology] // Vestnik Moskovskogo gosudarstvennogo oblastnogo universiteta. Seriya: Estestvennye nauki. 2015. no. 2. pp. 46-56.

16. Rozanov L.L. Geoekologovedenie: itogi i perspektivy [Geoecological science: results and prospects] // Vestnik Moskovskogo gosudarstvennogo oblastnogo universiteta. Seriya: Estestvennye nauki. 2015. no. 3. pp. 54-65.

17. Vozdeistvie dioksinov na okruzhayushchuyu sredu i zdorov'e cheloveka [Impact of dioxins on the environment and human health], Rumak V.S., CHin' Kuok Kkhan', Kuznetsov A.N. et al. // Vestnik Rossiiskoi akademii nauk. 2009. Vol. 79 (no. 2). pp. 124-130.

18. Sorokhtin O.G. Global'noe poteplenie: prichiny istinnye i mnimye [Global warming: true and imaginary causes] // Nauka v Rossii. 2010. no. 2. pp. 25-31.

19. Syvorotkin V.L. Vodorod - razrushitel' ozona [Hydrogen - destroyer of ozone] // Nauka v Rossii. 2000. no. 2. pp. 47-53.

20. Trubetskoi K.N., Galchenko Yu.P. Chelovek i priroda: protivorechiya i puti ikh preodoleniya [Man and nature: contradictions and ways of overcoming them] // Vestnik RAN. 2002. Vol. 72 (no. 2). pp. 405-409.

21. Tekhnogennye mineral'nye nanochastitsy kak problema osvoeniya nedr [Technogenic mineral nanoparticles as a problem of development of mineral resources], Trubetskoi K.N., Viktorov S.D., Galchenko Yu.P. et al. // Vestnik RAN. 2006. Vol. 76 (no. 4). pp. 318-324.

22. Frumin G.T. Ekologiya i geoekologiya: mify i real'nost' [Ecology and geoecology: myths and reality]. SPb., RGGMU, 2011. 236 p. 
23. Shestibratov K.A., Chubugina I.V., Zavriev S.K. Genno-inzhenernaya deyatel'nost': analiz mezhdunarodnykh i rossiiskoi zakonodatel'nykh baz [Genetic engineering activity: analysis of international and Russian legislative databases] // Mirovaya ekonomika i mezhdunarodnye otnosheniya. 2014. no. 12. pp. 50-59.

24. Yablokov A.V. Ob «ekologicheskoi chistote» atomnoi energii [About "ecologically clean" nuclear energy] Global'nye problemy biosfery [Vyp. 1] [Global problems of the biosphere [Iss. 1]]. M.: Nauka, 2003. pp. 62-94.

\section{ИНФОРМАЦИЯ ОБ АВТОРЕ}

Розанов Леонид Леонидович - доктор географических наук, профессор кафедры общей и региональной геоэкологии Московского государственного областного университета;

e-mail: rozanovleonid@mail.ru

\section{INFORMATION ABOUT THE AUTHOR}

Rozanov Leonid L. - doctor of geographical sciences, professor of the Chair of General and Regional Geoecology at the Moscow State Regional University; e-mail: rozanovleonid@mail.ru

\section{БИБЛИОГРАФИЧЕСКАЯ ССЫЛКА}

Розанов Л.Л. Производственная геоэкология: актуальная проблематика // Вестник Московского государственного областного университета. Серия: Естественные науки. 2016. № 1. С. 78-91.

DOI: $10.18384 / 2310-7189-2016-1-78-91$

\section{BIBLIOGRAPHIC REFERENCE}

L. Rozanov. Production geoecology: current issues // Bulletin of Moscow State Regional University. Series: Natural sciences. 2016. no 1. pp. 78-91.

DOI: 10.18384/2310-7189-2016-1-78-91 